\title{
The value of uncertainty: The Zika and Microcefalia link
}

\section{Denise Silva Matias', Luis Cláudio Lemos Correia², Daniel Oliveira Medina da Silva³, Larrie Rabelo Laporte ${ }^{4}$, Camila Verônica Souza Freire ${ }^{5}$, Gabriel de Araújo Grisi', Thiago Masashi Taniguchi ${ }^{7}$, Mariana Correia Moreira Cruz ${ }^{8}$}

${ }^{1}$ Corresponding author. BAHIANA - School of Medicine and Public Health. Salvador, Bahia, Brasil. ORCID: 0000-0003-1962-7623.dmatias@ultradiag.com.br

2BAHIANA - School of Medicine and Public Health. Salvador, Bahia, Brasil. ORCID: 0000-0002-6910-1366. luisclcorreia@gmail.com ${ }^{3}$ BAHIANA - School of Medicine and Public Health. Salvador, Bahia, Brasil. ORCID: 0000-0003-0534-1616. dan-medina@hotmail.com ${ }^{4}$ BAHIANA - School of Medicine and Public Health. Salvador, Bahia, Brasil. ORCID: 0000-0002-4252-4668. Iarrielaporte17.2@bahiana.edu.br ${ }^{5}$ BAHIANA - School of Medicine and Public Health. Salvador, Bahia, Brasil. ORCID: 0000-0003-1873-3512. camilafreire17.2@bahiana.edu.br ${ }^{6}$ BAHIANA - School of Medicine and Public Health. Salvador, Bahia, Brasil. ORCID: 0000-0003-4605-2220. gabrielgrisi15.2@bahiana.edu.br ${ }^{7}$ BAHIANA - School of Medicine and Public Health. Salvador, Bahia, Brasil. ORCID: 0000-0003-3458-510X. thiagotaniguchi16.2@bahiana.edu.br ${ }^{8}$ BAHIANA - School of Medicine and Public Health. Salvador, Bahia, Brasil. ORCID: 0000-0002-0943-701X. marianacruz17.1@bahiana.edu.br

\begin{abstract}
Scientific paradigm violations are common in the medical literature. This article aims to describe the principles that should guide scientific thinking, such as the philosophy of skepticism, the consideration of multiple hypothesis, epidemiological criteria to demonstrate association, concern about random errors and the need to quantify the strength of association. We use the hypothesis of causality between Zika and microcephaly to illustrate these principles and cognitive mechanisms that predispose to its violation. This is an example of dissociation between certainty and level of evidence, since the association between these two entities was confirmed at a time when there was no evidence of quality that supported this association.
\end{abstract}

KEYWORDS: Causality. Uncertainty. Zika virus. Microcephaly 
Unlike the title expressed, this text is not limited to the question of the possible causal link between Zika and microcephaly. We will treat this subject as a practical and contemporary example of a major phenomenon: epistemic arrogance.

The growth incidence of Zika in Brazil in 2015/2016 and apparentlymicrocephaly, constituteaninterestinghistory of hypothesis generation: Zika causes microcephaly. At that time, this hypothesis was transformed into indisputable truth in scientific publications and the lay press, sounding like science fiction.

Science fiction is a pertinent and paradoxical term. Paradoxical, as science is not fiction; this paradox is quite prevalent. This paradox translates the classic and quite common violation of the scientific principle of the null hypothesis. To this lack of humility in recognizing uncertainty, Nassim Taleb ${ }^{1}$, a scientist of uncertainty at the University of Massachusetts, calls epistemic arrogance, a common phenomenon of the human mind, that for evolutionary reasons, tends to underestimate the uncertainty that is present in hypotheses. This phenomenon became more evident when the conviction force of affirmations in favor of the causal relationship between Zika and microcephaly grew exponentially, despite the absence of real evidence.

At the time, there were numerous print and television reports, in which categorical claims by journalists were backed up by statements by professionals alleged to have authority to speak on the subject. They started recommending ${ }^{2}$ that women with longer fertility (up to 30 years) postpone their pregnancy plans, while women with less time could do so. In parallel, in a press release, the Ministry of Health ${ }^{3}$ confirmed the relationship between Zika and microcephaly, based on a case report ${ }^{4}$ of virus detection in a newborn who died.

There were also those who recognized the need for definitive proof, but they spoke with the connotation of fact. They said that "everything indicates", while recommending "preventive measures" (which measures?). Apparently, they were preserving the principle of the null hypothesis, but used this principle to generate a more credible scientific appearance, without realizing that they had already rejected the null hypothesis when they made the world behave as if causality was proven.
We need to reflect on the harm versus the advantages of precipitous rejection of the null hypothesis. In general, scientific thinking considers that Type I error (claiming something false - tolerance of 5\%) is scientifically more serious than Type II error (not stating something true - $20 \%$ tolerance). This should have been a valid reflection for that moment.

Karl Popper ${ }^{5}$, the greatest scientific philosopher of the last century, proposed that the proof of a hypothesis must go through the process of trying to refute it. We must begin by believing in nullity and changing our minds when the evidence in favor of the phenomenon goes beyond a lower threshold of doubt. The Zika and microcephaly case showed that we still do not understand what Popper proposed, the role of the null hypothesis. Thus, scientific myopia prevails, with its various components to be described below.

\section{The scientific myopia}

Considering that the proper fight against Zika should occur independently of the creation of pseudoscientific facts, we need to reflect whether this scientific myopia brings (individually and culturally) more benefits or losses. Scientific myopia is evident when we observe the great gap between everyday human thinking and scientific reasoning. In the history of mankind, only recently the "scientific thinking" has been contributing to our individual survival, whereas, in relation to the survival of the species, there has not yet been sufficient time for the "thought" to contribute. Our natural selection was not made for the ability to think, but for the ability to run. Maybe those who thought died more (because they ran less). For this reason, being skeptical and questioning is not our natural state, we need to condition ourselves to the scientific paradigm.

In fact, some think that science is one thing, practical life is another. At the time, in an article published in Folha de São Paulo ${ }^{6}$, the representative of PAHO (Pan American Health Organization) in Brazil, stated that "I have no doubt of the link between Zika and microcephaly", and "possibly some scientists believe that it is necessary more evidence, but as a public health professional I have no doubt. " These statements illustrate this thought well. 
The sentences propose a gap between science and practical life. It is necessary to understand that science is nothing more than the most honest way of portraying nature, since the scientific method does not serve to create knowledge but to describe the world, preventing itself against scientifically recognized phenomena: cognitive biases, biases of observation and effect of a chance.

\section{Uncertainty myopia}

We understand it is difficult to recognize the uncertainty, present in all activities, not only at the academic field, but specially to laypeople. A decision must be taken within this context, facing without hiding them under false concepts, practicing the statistical thinking. Descartes had affirmed all is doubtful, nothing could consider a priori as right, except: "since I think, I exist", basis of Cartesian thought. Benjamin Franklin, following the same thought, said, "in this world nothing can be said to be certain, except death and taxes." In uncertainty myopia, we don't recognize how much thoughts that "make sense" are uncertain. Our logic must serve as a basis to give plausibility to a hypothesis, not to generate facts (except extreme plausibility). Hypothesis medicine is full of examples that appear to make sense, although it shows opposite differences to logical beliefs, despite being uncertain. We tend to believe since we have some way to explain.

At that time, it made sense suppose that Zika infection was responsible for the rising number of microcephaly cases, by three reasons: some virus can impair nervous system embryogenesis during the first pregnancy trimester; the cases of Zika infection had increased; microcephaly cases had also increased. Given those facts, was concluded that Zika infection causes microcephaly, forgetting that makes sense is not the same as being a fact. Experts who made confident or almost confident statements of this fact did not realize the degree of uncertainty in these statements.

\section{Hypotheses myopia}

This is a cognitive bias caused by a retrospective analysis of the history of scientific findings.
Retrospectively, the world had a platonic aspect that seemed like everything used to make a lot of sense before the evidence. Although for each proven explication based in evidences there were plenty of hypothesis before them and not always the one who sounded more logical were the one that prevailed. The hypothesis that are not proven will be forgotten, lasting only the winner hypothesis as part of the narrative of the history, suggesting that a discovery was made for a single one hypothesis created, that was verified and proved.

In fact, for each discovery, numerous hypotheses have been rejected; commonly the most likely is among these. Usually, the favorite hypothesis is more likely to win than to lose. Being the most likely does not mean to be very likely.

Observe an Olympic marathon winner. Unlike 100 meters, this type of proof has the result influenced by a more complex process. It is almost unpredictable to know who will win; in fact, everyone is almost as likely. On the other hand, after the race is over, the winner wins the title of being the best and it makes a lot of sense that he was the winner. We always find explanations, talent, training, etc. After the result, our mind overestimates the previous probability of that result.

The causes of congenital microcephaly are complex and multifactorial, including chromosomal abnormalities, exposure to chemicals or toxins, intrauterine infections, craniosynostosis, maternal diseases ${ }^{7}$ and environmental factors ${ }^{8}$. Just to name a few.

This lack of understanding has led people to overestimate the likelihood that Zika is the explanation for microcephaly, to the point that it is confirmed or strongly suggestive. This is a narrative fallacy when any important event gains an obvious explanation after it occurs.

\section{Epidemiological myopia}

Epidemiological myopia is characterized by confusion that exists between the basic concepts of coexistence and association. The term "association" (or relationship) was the most commonly used term by numerous experts and journalists in publications on zika and microcephaly ${ }^{9}$. However, it was misused because this is an example of coexistence and not of 
association ${ }^{4}$. The fact that a woman whose child was born with microcephaly could have had a Zika virus infection in the first trimester, or the fact that the virus was identified in some newborns with microcephaly wasn't an association because there was no silent evidence, or that is, cases of normocephalic child with history of Zika in pregnancy and cases of microcephaly without a history of Zika.

To characterize an association, it is essential to estimate the proportion of children with microcephaly whose mothers actually had Zika infection during pregnancy compared with the proportion of children who were born normal whose mothers also had the disease during pregnancy (case-control study). Without these data, we could not speak of association nor causality. At that point, we were very far from what could be considered probable and still much further from the rejection limit of the null hypothesis. Even if the association was proven, this would be the first step in demonstrating causation. There are many true but non-causal associations.

Regarding temporality, this is another epidemiological myopia because we know that temporal association is a great fallacy. Events can grow or fall together without any causal relationship. The book Spurious Correlations ${ }^{10}$ gives us interesting examples of the fallacy of temporal association ${ }^{6}$.

\section{Statistical myopia}

This is the most common of myopia, which stems from the lack of awareness that we need a denominator to quantify the risk of outcomes. This denominator was not presented in the doctors' testimonials or press reports.

Data from a growth in the number of microcephaly registrations were reported from 30 to 1.200 cases in three months. This was quite frightening, as numbers in excess of thousands carry the connotation of great risk. The pregnant women panicked! However, risk is a probability arising from total outcomes divided by the total number of people vulnerable to the outcome. Dividing 1.200, which corresponds to the number of suspected microcephaly cases (outcomes) detected in the last three months of 2015, by the average number of live births in Brazil (vulnerable to the outcome) in this period (around 600,000), we will reach a 0.19\% risk of a child being born with microcephaly for all possible causes, not just for Zika. If we consider the optimistic scenario that half of these cases were due to Zika, we would say that $0.095 \%$ was the risk of Zika microcephaly.

The Zika virus causes mild febrile acute illness, and since its discovery until 2007 , only rare cases of Zika virus infection have been confirmed in Africa and Southeast Asia. In the major epidemic on Yap Island in Micronesia ${ }^{11}$, the rate of infection was estimated at $73 \%$ (3/4 of the population), with $61 \%$ women and no reference to pregnant women. No cases of hospitalization or death were reported either. So why so much panic?

The panic resulted from the binding of Zika virus with microcephaly. From the identification of the outbreak in Brazilian territory and the concomitance with the increase of microcephaly cases manifested by an increase of 20 times incidence ${ }^{12}$ in 2015 compared to the number notified in 2014, the Ministry of Health admitted a causal relationship ${ }^{13}$. There was no definitive proof of any causal relationship ${ }^{14}$, apart from the fact that until that moment, no other flaviviruses were associated with central nervous system teratogen. Nevertheless, some publications have assumed a strong probability of the causal relationship between these two entities ${ }^{15,16}$.

Statistical myopia made doctors recommend that women not get pregnant. They forgot that the set of other possible infections that could cause sequelae in babies far outweighed the risk of Zika microcephaly.

\section{What Kant would say?}

According to Kant ${ }^{17}$, the interpretation of reality is involuntary and strongly influenced by the unconscious. Cognitive psychologists later confirmed his philosophy. Regarding the microcephaly "epidemic", Kant would probably justify the increase in the number of cases due to a cognitive-influenced perception problem of people already influenced by the trend. This reasoning may seem too skeptical to suggest that the problem does not exist, but it becomes perfectly plausible when we think of the possibility of overestimation of the problem. 
The health professionals involved in the diagnosis of microcephaly were involuntarily biased by the trend, which implied a notion of increased pretest probability, in addition to the cognitive comfort that presents itself when it becomes more comfortable to laud according to the outside world than to do it independently. This increases sensitivity over specificity by generating a trivialization of diagnoses.

Microcephaly refers to a cranial circumference with more than two standard deviations below the average for the child's age and gender? ${ }^{7}$ However, establishing the microcephaly criterion above three below-average standard deviations, as proposed by the ECLAMC18 would increase specificity by reducing the iatrogenic potential of newborn brain radiation during CT for diagnostic confirmation. In addition, it would help alleviate the emotional effects of parents who receive a false-positive screening assessment and reduce the burden and costs of an already overburdened health system ${ }^{14}$.

There was subjectivity in many cases. Prenatal diagnosis is difficult before the third trimester of pregnancy and is usually made by ultrasound ${ }^{19}$. Earlier there was little talk of the problem, so the sensitivity of sonographers was not focused on it. From the disclosure of the cases, the main idea that was in the mind of these and the pregnant woman before the examination is that there were signs of microcephaly.

In the public health care system, less pregnant women were likely to have ultrasound, so it is very plausible to believe that in the past there was underreporting. In an interesting article published in Estadão ${ }^{20}$, biologist Fernando Reinach made a parallel between the cases of microcephaly that occur in the United States and those that were reported in Brazil. The Ministry of Health reported that in 2014, 147 cases were reported. If we estimate that 3 million births occur each year in Brazil and that the frequency of microcephaly is similar to what occurs in the US21 (0.6\% annually), 19.250 children with microcephaly should be born. Thus, there was plausible underreporting in the past and overreporting at the time of the outbreak.

\section{Update of the evidences for 2018}

After three years since the epidemic infection of Zika virus and the increase of the number of microcephaly cases in Brazil, the researchers are still searching for answers to those epidemiological questions. At first, the concern was to identify the causal factor and a series of possible etiologies that had been published. Besides the congenital infection by the Zika virus, the exposition to pesticides, vaccines during pregnancy and, naturally, the overdiagnosis for microcephaly were suggested. Subsequently some in vitro and animal models evidences ${ }^{22,23}$, which demonstrated the presence of viral RNA in many tissues of infected females' brooding, especially in the brain, the research spotlight changed from the etiology to the biological mechanisms. However, various questions currently remain without answers, such as risk factors, physiopathology, maternal-fetal disease transmission time, including the mechanisms of the fetal brain damage and microcephaly, and the role of other cofactors, like viral load, viremia duration and host genetic.

An ecological analysis ${ }^{24}$ demonstrated that despite the uniform distribution across all the country regions, was in the Northeast where the majority number of microcephaly cases occur. Not by coincidence, this region is the one with more poverty and an increased risk of domestic Aedes aegipti as result of the larvae breeding grounds facilitated by the human actions. Some authors defend the hypothesis of that the expansion of the microcephaly occurrence may not be related only to Zika virus, but also connected to the poverty and previous coinfection to other pathogens (Dengue virus, Chikungunya virus, etc.) $)^{25,26}$.

Some prospective work begins to sketch clues to the true association between Zika and microcephaly ${ }^{27-33}$ but embracing cohort studies will be needed to clarify many existing gaps. In a literature review (Table 1) we found that the vast majority of publications on the subject are case reports, case series and reviews. We found only 7 prospective studies, including 1 cohort $^{34}$ and 2 case-contro| ${ }^{35,36}$, evaluating gestational outcomes. These studies show that there is evidence that Zika virus has the ability to cross the placental barrier and infect neural progenitor cells in the developing fetus, as in animal models, causing congenital problems particularly in the first trimester ${ }^{37-39}$. There is also some evidence of Zika neurotropism by the human adult central nervous system related to Guillan-Barré Syndrome, but these findings are equally temporary ${ }^{40-44}$. Confirmation of this neurotropism requires more case studies and other evidence needed for a causal association. 


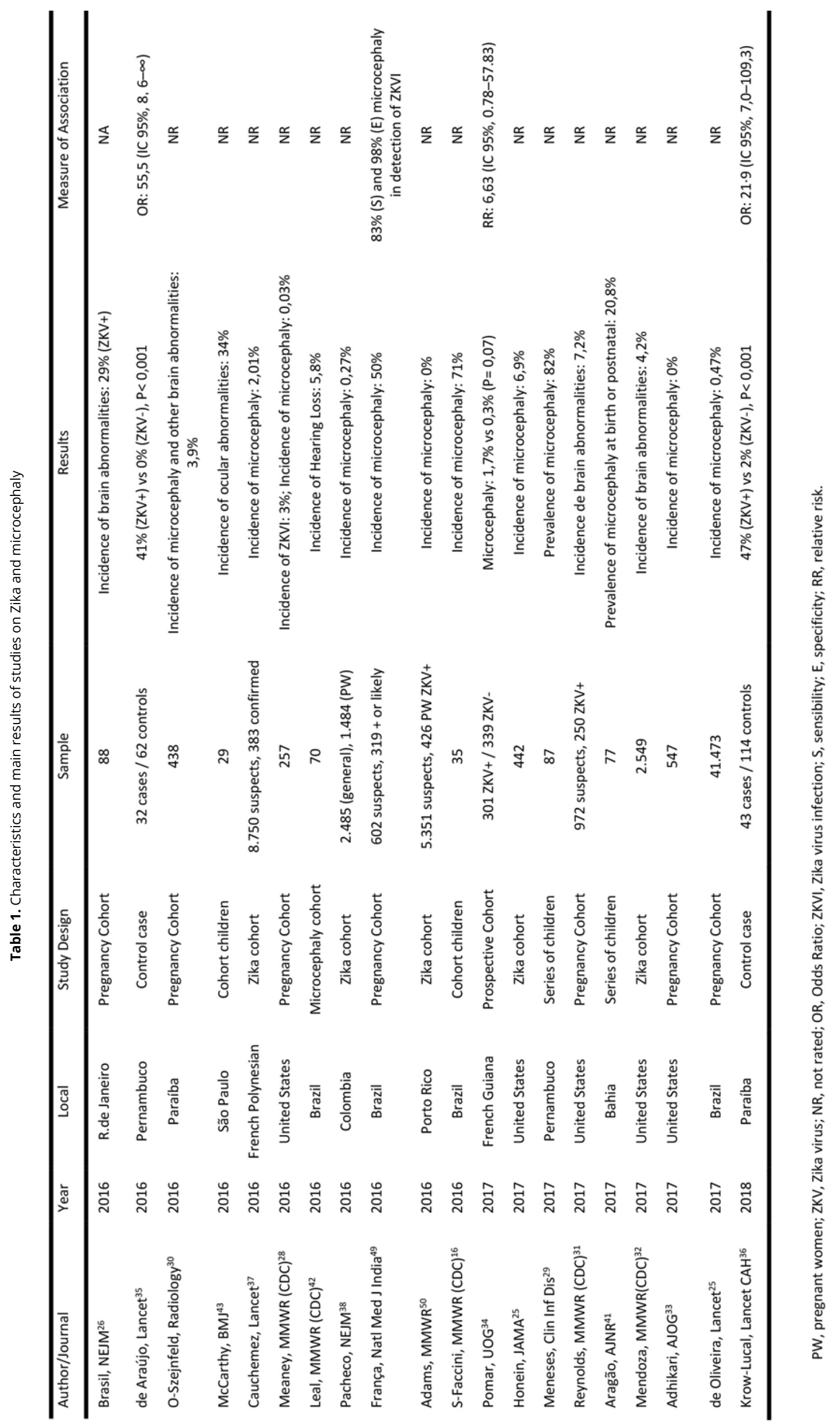


Others retrospective studies evaluated outcomes in newborns or children from mothers that were presumably infected during pregnancy ${ }^{45-47,16}$. These types of studies, related to the inclusion of newborns or infants, increase the probability of reminiscent bias by the mother (remember similar symptoms of the Zika virus infection), being plausible that some woman or children could had been infected after birth and not during the pregnancy. Furthermore, the abovementioned studies limit the comprehension of the Zika virus infection during gravidity.

Despite the dearth of robust observational studies, many publications continue to suggest, based on beliefs, the causal association between Zika and microcephaly ${ }^{48,49,15,4,23,50}$. Some based on Shepard teratogenicity ${ }^{46}$ or Bradford Hill causality criteria ${ }^{47}$ (not all satisfied), while others based on retrospective data providing risk and lethality estimates ${ }^{37,44,38}$. However, these estimates were based on small sample sizes, large confidence intervals, lack of control for confounding effects, and lack of assessment of other adverse outcomes such as other brain abnormalities.

Zika virus infection has been spreading worldwide and is endemic in many countries in Asia and Africa, with many asymptomatic exposures, including in pregnant women. However, there is no infected newborn born from an infected mother, nor is microcephaly a problem in these regions ${ }^{48}$. What is the reason for the high prevalence of microcephaly in babies born to mothers infected with Zika virus in South America? Cohorts developed in other regions of Brazil and Latin America may provide further evidence on whether there are variations in risk according to the location studied and, if so, what is the reason for these variations.

These and other questions should be answered by large prospective studies that are in progress subsidized by the World Health Organization, the Medical Research Council, the Welcome Trust, the British Department for International Development, the Horizon platform 2020 of the EU and the USA.

But we must be aware of the greater peculiarity of this scientific question: the null hypothesis was hastily rejected, making room for the biases of confirmation and publication.

\section{Author contributions}

Correia LCL and Matias DS - idealization and article writing, spelling and grammar review. Other co-authors performed the translation of the manuscript and spelling and grammar review.

\section{Competing interests}

No financial, legal or political competing interests with third parties (government, commercial, private foundation, etc.) were disclosed for any aspect of the submitted work (including but not limited to grants, data monitoring board, study design, manuscript preparation, statistical analysis, etc.).

\section{References}

1. Taleb NN. The black swan: the impact of the highly improbable. 2. Ed. Random House, New York; 2010.

2. G1. Especialistas tiram dúvidas mais frequentes sobre a microcefalia. [Internet]. 2015. Available at: http://g1.globo.com/ fantastico/noticia/2015/12/especialistas-tiram-duvidas-maisfrequentes-sobre-microcefalia.html

3. Ministério da Saúde. Blog da Saúde. Ministério da Saúde confirma relação entre vírus Zika e microcefalia. [Internet]. 2015. Available at: http://portalsaude.saude.gov.br/index.php/cidadao/ principal/agencia-saude/21014- ministerio-da-saude-confirmarelacao-entre-virus-zika-e-microcefalia.

4. Mlakar J, Kowa M, Tul N, Popovic M, Poljsak-Prijatelj M, Mraz J et al. Zika Virus Associated with Microcephaly. N Engl J Med. 2016; 374(10):951-958. doi: 10.1056/NEJMoa1600651

5. Schmidt P, Santos JL. O pensamento epistemológico de Karl Popper. Contexto, 2007; 7(11):1-15.

6. Jornal Folha de São Paulo. Não tenho dúvida do elo entre zika e microcefalia. [Internet]. 2015. Disponível em: http://www1. folha.uol.com.br/cotidiano/2015/12/1715921-evidencia-entremicrocefaliae-zika-e-forte-diz-diretor-da-opas-no-brasil.shtml.

7. Harris SR. Measuring head circumference: Update on infant microcephaly. Can Fam Physician. 2015; 61(8):680-4.

8. Elliott P, Briggs D, Morris S, Hoogh C, Hurt C, Jensen TK et al. Risk of adverse birth outcomes in populations living near landfill sites. BMJ. 2001; 323:363-368. doi: 10.1136/bmj.323.7309.363

9. Santos JLF, Matias DS, Novaes NN. O paradigma científico no discurso da mídia brasileira sobre Zika e Microcefalia. Rev Inter Educ Saúde. 2018; 2(1). doi:10.17267/2594-7907ijhe.v2i1.1605

10. Vigen T. Spurious Correlations - Correlation is not Causation. Hachette Books; 2015. 
11. Duffy MR, Chen TH, Hancock WT, Powers AM, Kool JL, Lanciotti RS et al. Zika Virus Outbreak On Yap Island, Federated States of Micronesia. N Engl J Med. 2009; 360:2536-2543.

12. Fanci AS and Morens DM. Zika Virus in the Americas - Yet Another Arbovirus Threat. N EngI J Med (available at NEJM org), 2016; 1-3.

13. Ministério da Saúde. Secretaria de Vigilância em Saúde. Protocolo de vigilância e resposta à ocorrência de microcefalia relacionada à infecção pelo vírus Zika. [Internet]. 2015.

Available at: http://portalsaude.saude.gov.br/images/pdf/2015/ dezembro/08/microcefalia-protocolode-vigilancia-e-resposta-v1-2. pdf

14. Victora CG, Schuler-Faccini L, Matjasevich A, Ribeiro EM, Pessoa A, Barros FC. Microcephaly in Brazil: How to interpret reported numbers? Lancet. 2016; 387(10019):621-4. doi: 10.1016/ s0140-6736(16)00273-7

15. Oliveira Melo AS, Malinger G, Ximenes R, Szejnfeld PO, Alves Sampaio S, Bispo de Filippis AM. Zika virus intrauterine infection causes fetal brain abnormality and microceplaly: tip of the iceberg? Ultrasound Obstet Gynecol. 2016;47(1):6-7. doi: 10.1002/ uog.15831

16. Schuler-Faccini L, Ribeiro EM, Feitosa IML, Horovitz DDG, Cavalcanti DP, Pessoa A et al. Possible Association Between Zika Virus Infection and Microcephaly - Brazil, 2015. Morb Mortal Wkly Rep. 2016;65(3):59-62. doi: 10.15585/mmwr.mm6503e2

17. Silveira FL. A teoria do conhecimento de Kant: $\mathrm{O}$ idealismo transcendental. Cad Cat Ens Fis, 2002; 928-51.

18. Latin American Collaborative Study of Congenital Malformation - final document, 2016. Available at: http://www eclamc org/eng/index php

19. Den Hollander NS, Wessels MW, Los FJ, Ursem NTC, Niermeiger MF, Wladimiroff JW. Congenital microcephaly detected by prenatal ultrasound: genetic aspects and clinical significance. Ultrasound Obstet Gynecol. 2000; 15(4):282-7. doi: 10.1046/j.1469-0705.2000.00092.x

20. Estadão. Microcefalia que sempre existiu. [Internet]. 2016. Available at: https://saude.estadao.com.br/noticias/ geral,microcefalia-que-sempre-existiu,10000015230

21. Ashwal S, Michelson D, Plawner L, Dobyns WB. Practice Parameter: Evaluation of the child with microcephaly (an evidence-based review). Neurology. 73(11):887-97. doi: 10.1212/ WNL.0b013e3181b783f7

22. Caine EA, Jagger BW, and Diamond MS. Animal Models of Zika Virus Infection during Pregnancy. Viruses, 2018; 10(11):pii: E598. doi: 10.3390/v10110598

23. Tang BL. Zika virus as a causative agent for primary microencephaly: the evidence so far. Arch Microbiol. 2016; 198(7):595-601. doi: 10.1007/s00203-016-1268-7
24. Campos MC, Dombrowski JG, Phelan J, Marinho CRF, Hibberd $\mathrm{M}$, Clark TG et al. Zika might not be acting alone: Using an ecological study approach to investigate potential co-acting risk factors for an unusual pattern of microcephaly in Brazil. PLoS ONE. 2018;13(8):e0201452. doi: 10.1371/journal.pone.0201452

25. Oliveira WK, França GVA, Carmo EH, Duncan BB, Kuchenleecker RS, Schmidt MI. Infection-related microcephaly after the 2015 and 2016 Zika virus outbreaks in Brazil: a surveillance-based analysis. Lancet. 2017; 390(10097):861- 870. doi: 10.1016/S0140-6736(17)31368-5

26. Brasil P, Pereira Jr JP, Gabaglia CR, Damasceno L, Wakimoto M, Nogueira RMR et al. Zika Virus Infection in Pregnant Women in Rio de Janeiro - Preliminary Report. N Engl J Med. 2016; 375(24):2321-2334. doi: 10.1056/NEJMoa1602412

27. Honein MA, Petersen EE, Jones AM, Lee EH, Yadzy MM, Ahmad N, and Macdonald J, et al. Birth Defexts Among Fetuses and Infants of US Women with Evidence of Possible Zika Virus Infection During Pregnancy. JAMA. 2017; 317(1):59-68. doi: 10.1001/jama.2016.19006

28. Meaney-Delman D, Hills SL, Williams C, Galang RR, lyengar R, Hennenfent AK et al. Zika Virus Infection Among U.S. Pregnant Travelers - August 2015- February 2016. MMWR Morb Mortal Wkly Rep. 2016; 65(18):211-4. doi: 10.15585/mmwr.mm6508e1

29. Meneses JDA, Ishigami AC, Melo LM, Albuquerque LL, Brito CAA, Cordeiro MT et al. Lessons Learned the Epicenter of Brazil's Congenital Zika Epidemic: Evidence From 87 Confirmed Cases. Clin Infect Dis. 2017; 64(10):1302-1308. doi: 10.1093/cid/ cix166

30. Oliveira-Szejnfeld PS, Levine D, Melo ASO, Amorim MMR, Batista AGM, Chimelly L, Tanuri A, Aguiar RS, Malinger G, Ximenes R, Robertson R, Szejnfeld J, and TovarMoll F. Congenital Brain Abnormalities and Zika Virus: What the Radiologist Can Expect to See Prenatally and Postnatally. Radiology. 2016; 281(1):203-18. doi: 10.1148/radiol.2016161584

31. Reynolds MR, Jones AM, Petersen EE, Lee EH, Rice ME, Bingham A et al. Vital Signs: Update on Zika Virus-Associated Birth Defects and Evaluation of All U.S. Infants with Congenital Zika Virus Exposure - U.S. Zika Pregnancy Registry. 2016. MMWP Morb Mortal Wkly Rep, 2017; 66(13):366-373. doi: 10.15585/mmwr. mm6613e1

32. Shapiro-Mendoza CK, Rice ME, Galang RR, Felton AC, VanMaldeghem K, Prado MV, and Elis E, et al. Pregnancy Outcomes After Maternal Zika Virus Infection During Pregnancy US Territories, January 1, 2016 - April 25, 2017. Morb Mortal Wkly Rep. 2017; 66(23):615-621. doi: 10.15585/mmwr.mm6623e1

33. Adhikari EH, Nelson DB, Johnson KA, Jacobs S, Rogers VL, Roberts SW et al. Infants outcomes among women with Zika virus infection during pregnancy: results of a large prenatal Zika screening program. Am J Obstet Gynecol. 2017; 216(3):292.e1-292. e8. doi: 10.1016/j.ajog.2017.01.018 
34. Pomar L, Malinger G, Benoist G, Carles G, Ville Y, Rousset D et al. Association between Zika virus and fetopathy: a prospective cohort study in French Guiana. Ultrasound Obstet Gynecol. 2017; 49(6):729-736. doi: 10.1002/uog.17404

35. Araújo TVB, Rodrigues LC, Alencar Ximenes RA, Miranda-Filho BD, Montarroyos UR, Melo APL et al. Association between Zika virus infection and microcephaly in Brazil, January to May, 2016: preliminary report of a case-control study. Lancet Infect Dis. 2016; 16(12):1356-1363. doi: 10.1016/S1473-3099(16)30318-8

36. Krow-Lucal ER, Andrade MR, Cananéa JNA, Moore CA, Leite $\mathrm{PL}$, Biggerstaff $\mathrm{BJ}$ et al. Association and birth prevalence of microcephaly attributable to Zika virus infection among infants in Paraíba, Brazil, in 2015-16: a case-control study. Lancet Child Adolesc Health. 2018; 2(3):205-213. doi: 10.1016/S23524642(18)30020-8

37. Cauchemez S, Besnard M, Bompard P, Dub T, GuillemetteArtur $P$, EyrolleGuignot $D$ et al. Association between Zika virus and microcephaly in French Polynesia. 2013-15: a retrospective study. The Lancet, 2016; 387(10033):2125-2132. doi: 10.1016/S01406736(16)00651-6

38. Pacheco O, Beltrán M, Nelson CA, Valencia D, Tolosa N, Farr SL, and Padilla AV et al. Zika Virus Disease in Colombia - Preliminary Report. N Engl J Med, 2016. doi: 10.1056/NEJMoa1604037

39. Pomar L, Vouga $M$, Lambert $\mathrm{V}$, Pomar $\mathrm{C}$, and Hcini $\mathrm{N}$. Maternal-fetal transmission and adverse perinatal outcomes in pregnant women infected with Zika virus: prospective cohort study in French Guiana. BMJ. 2018;363:k4431. doi: 10.1136/bmj. k4431

40. Broutet N, Krauer F, Riesen M, Kalakdina A, Almiron M, Aldighieri S, Espinal M, Low N, and Dye C. Zika Virus as a Cause of Neurologic Disorders. N Engl J Med, 2016; 374(16):1506-1509. doi: 10.1056/NEJMp1602708

41. Aragão MFVV, Holanda AC, Brainer-Lima AM, Petribu NCL, Castillo M, Van Der Linden V et al. Nonmicrocephalic Infants with Congenital Zika Syndrome Suspected Only after Neuroimaging Evaluation Compared with Those with Microcephaly at Birth and Postnatally: How Large is the Zika Virus "Iceberg". Am J Neuroradiol. 2017; 38(7):1427-1434. doi: 10.3174/ajnr.A5216

42. Leal MC, Muniz LF, Ferreira TSA, Santos CM, Almeida LC, Van Der Linden V, Ramos RCF, Rodrigues LC, and Caldas Neto SS. Hearing Loss in Infants with Microcephaly and Evidence of Congenital Zika Virus Infection - Brazil, November 2015 - May 2016. Morb Mortal Wkly Rep. 2016; 65(34):917-919. doi: 10.15585/ mmwr.mm6534e3external icon

43. McCarthy M. Severe eye damage in infants with microcephaly is presumed to be due to Zika virus. BMJ, 2016; 352-i855. doi: 10.1136/bmj.i855
44. Cunha AJ, Magalhães-Barbosa MC, Lima-Setta F, Medronho RA, Barbosa PA. Microcephaly Case Fatality Rate Associated with Zika Virus Infection in Brazil: Current Estimates. Pediatr Infect Dis J. 2017; 36(5):528-530. doi: 10.1097/INF.0000000000001486

45. Wang JN, Ling F. Zika Virus Infection and Microcephaly: Evidence for a Causal Link. Int J Environ Res Public Health, 2016; 13(10):pii: E1031. doi: 10.3390/ijerph13101031

46. Shepard TH. "Proof" of Human Teratogenicity. Teratology, 1994; 50(2):97-8. doi: 10.1002/tera.1420500202

47. Bradford Hill A. The Environment and Disease: Association or Causation? Proc R Soc Med. 1965; 58(5):295-300.

48. Joob B. Letters to the Editor: Regarding Zika Microcephaly. Innov Clin Neurosci. 2018; 15(7-8):11-14.

49. França GVA, Shuler-Faccini L, Oliveira WK, Henriques CMP, Carmo EH, Pedi VD et al. Congenital Zika virus syndrome in Brazil: a case series of the first 1501 livebirths with complete investigation. The Lancet, 2016;388(10047):891-7. doi: 10.1016/ S0140-6736(16)30902-3

50. Adams L, Bello-Pagan M, Lozier M, Ryff KR, Espinet C, Torres J et al. Update: Ongoing Zika Virus Transmission - Puerto Rico, November 1, 2015-July 7, 2016. MMWR (CDC), 2016; 65(30):774779. doi: $10.15585 / \mathrm{mmwr} . \mathrm{mm} 6530 \mathrm{e} 1$ 